\title{
OVERCOMING LISTENING PROBLEMS RELATED TO LISTENERS' PSYCHOLOGICAL CHARACTERISTICS AS A WAY TO ENHANCE GOOD ATTITUDE TOWARD ENGLISH LANGUAGE TEACHING
}

\author{
Dwi Rahayu ${ }^{1}$, Chusna Apriyanti ${ }^{2}$ \\ STKIP PGRI PACITAN \\ ${ }^{1}$ rahayudwi949@yahoo.com \\ ${ }^{2}$ chusna.apriyanti@gmail.com
}

\begin{abstract}
This paper aims to know the listening problems related to listeners' psychological characteristics and the strategies to solve those problems. The researchers used descriptive qualitative research design. The data are collected through observation and giving questionnaire to the students on listening class of English Education Study Program grade I STKIP PGRI Pacitan academic year 2016-2017. The result shows that there are five problems related to psychological characteristic. First, the students feel nervous and worried when they do not understand the spoken text. Second, the students have difficulties in understanding the spoken text, which is of their interest. Third, they stop listening when they have problems in understanding a listening text. Fourth, they feel disappointed when they do not have total comprehension. Fifth, before listening, they fear that they cannot understand the text. Based on these problems, the lecturer gives some solving strategies. First, the lecturer provides the text based on the students' level and ages. This is also related to the vocabularies ability. Second, the lecturer provides listening tasks that arouse students' interest. The lecturer gives different inputs, such radio, TV, songs, lectures, advertisement. Third, the lecturer gives extra time in each section to motivate the students in answering the task. Fourth, the lecturer provides listening task's background knowledge. Besides, the lecturer gives feedback to increase students' motivation. Fifth, lecturer should encourage their students to develop listening strategies, such as predicting, asking for clarification, and using non-verbal cues to improve learners' listening comprehension ability.
\end{abstract}

Keywords: listening problem, listening strategies, listeners' psychological characteristics

\section{INTRODUCTION}

Listening is very important in humans' lives. The conversation happens because of the speakers' ability in listening the other speakers' speech. Through listening skill, people can understand other people explanation or speech. Listening is one of the learning English skills, together with speaking, reading, and writing. Each of those skills has different characteristics in implementing toward the students in the English class.

In Indonesia, English is admitted as the foreign language. It makes English is taught as the local content in elementary private school and rarely used in the formal events. Among the four skills above, listening is the most difficult skill for students. Some students feel that listening is the "stressor" for the in learning English. Those conditions absolutely give effects on their listening ability. Stress is related to the psychological factor. Moreover, when we talk about psychology of the learners, it cannot be so independent. Absolutely, many factors caused those problems. The lack of interest and motivation makes them cannot enjoy listening. Therefore, to avoid this problem, the teacher should provide the strategies in overcoming the students' listening problem. 


\section{LITERATURE REVIEW}

According to Atasheneh and Izzadi (179:2012), the listening is the ability to identify and understand what others are saying. While Rivers (1991:151) in this regard pointed out that speaking does not of itself, constitute communication unless what is being said is comprehended by another person. Nevertheless, undeniable, in teaching English as the foreign language in Indonesia, listening is one of the most difficult skills in learning English. It seems a stressor for the students.

Some students also have low ability dealing with listening. It is caused by many problems. It can be based on the students intrinsic factors problems, like their low motivation, their low interest, their anxiety, their willingness to learn listening, etc. besides, it can be caused by the extrinsic factors problems, such as the difficult and unfamiliar listening task, the environment, the equipment, the lecturer, etc. According to Yagang (1994), the problems in listening were accompanied with the four following factors: the message, the speaker, the listener and the physical setting. While Higgins (1995), states that the problems were believed to cause by the speech rate, vocabulary and pronunciation. In addition, Flowerdew \& Miller (1996) assume that the problems of the students were for the speed of delivery, new terminology and concept, difficulty in focusing and the physical environment.

Focusing on the intrinsic factors, the students' psychological factor plays the important point in students' listening ability. Actually, it is related to the students' anxiety, but the psychological factor is broader than the anxiety. Anxiety is only one example of psychological factors even though it plays the highest problem in listening class. The students' psychological factor does not stand alone, but it happens because the supporting factors from the combination between intrinsic and extrinsic factors above. According to Yagang (1993), the listening comprehension process is also a relatively complex psychological process. In psychology, it is stated that when a person feels nervous or anxious he or she may not be concentrated. When one felt uncomfortable, his or her ability to listen is greatly reduced. Boredom and frustration are other barriers to listening comprehension.

According to Hamouda, (2013:19), the psychological problem occurs as a result of poor stimulation caused by disinterest in the topic, lack of motivation, failure in the part of the teacher to present meaningful material in a stimulating manner, or presenting the lecture in a monotone instigating sleep. He also adds that boredom and frustration may affect the extent to which attention is paid to listening.

\section{METHODS}

The researchers used descriptive qualitative research design. The data are collected from the students on listening class of English Education Study Program grade I STKIP PGRI Pacitan academic year 2016-2017. The class consists of 18 students. The techniques in collected data are through observation, interview and questionnaire. The questionnaire consists of two sections: section one contains 6 items dealing with students' perception to the importance of listening comprehension in learning language. While, section two includes 45 items dealing with listening problems encountered by the students. The questionnaire uses four point Likers Scale. The four points are never, sometimes, often, and always. While, the interview question will be both in English and Indonesian language version used as a guideline in conducting the interview. After having been collected, the data are analyzed by using the following process: analyze the data of students' perception to the importance of studying, elaborate the strategies for teachers and students to overcome the listening, and draw the conclusion. 


\section{FINDINGS AND DISCUSSION}

\subsection{The Listening Problems Related to Psychological Characters}

The result shows that there are five kinds of listening problems related to psychological characters. Those problems are showed in the following table:

Table 1: Five Kinds of Listening Problems Related to Psychological Characters

\begin{tabular}{|c|c|c|c|c|c|}
\hline $\begin{array}{c}\text { Item } \\
\text { No }\end{array}$ & Statements & Never & Sometimes & Often & Always \\
\hline \multirow[t]{2}{*}{1.} & \multirow[t]{2}{*}{$\begin{array}{l}\text { I feel nervous and worried when I don't } \\
\text { understand the spoken text }\end{array}$} & 1 & 9 & 8 & 0 \\
\hline & & $6 \%$ & $50 \%$ & $44 \%$ & $0 \%$ \\
\hline \multirow[t]{2}{*}{2.} & \multirow[t]{2}{*}{$\begin{array}{l}\text { I find it difficult to understand the spoken text } \\
\text { which is not of interest to me }\end{array}$} & 2 & 15 & 1 & 0 \\
\hline & & $11 \%$ & $83 \%$ & $6 \%$ & $0 \%$ \\
\hline \multirow[t]{2}{*}{3.} & \multirow[t]{2}{*}{$\begin{array}{l}\text { I stop listening when I have problems in } \\
\text { understanding a listening text }\end{array}$} & 6 & 9 & 3 & 0 \\
\hline & & $33 \%$ & $50 \%$ & $17 \%$ & $0 \%$ \\
\hline \multirow[t]{2}{*}{4.} & \multirow[t]{2}{*}{$\begin{array}{l}\text { If I don not arrive at a total comprehension of an } \\
\text { oral text, I feel dissapointed }\end{array}$} & 0 & 6 & 7 & 5 \\
\hline & & $0 \%$ & $33 \%$ & $39 \%$ & $28 \%$ \\
\hline \multirow[t]{2}{*}{5.} & \multirow[t]{2}{*}{$\begin{array}{l}\text { Before doing listening comprehension tasks, I } \\
\text { fear that I cannot understand what I will hear }\end{array}$} & 3 & 9 & 6 & 0 \\
\hline & & $17 \%$ & $50 \%$ & $33 \%$ & $0 \%$ \\
\hline
\end{tabular}

Those five factors become the listening problems for the students in the first semester of English Education Study Program STKIP PGRI Pacitan. Those five factors will be further described in the following discussion:

\subsubsection{The students feel nervous and worried when they do not understand the spoken text.}

When the students are asked about the nervousness and worries, 8 students from the total 18 students or $44 \%$ answer 'often'. It means that majority of the students feel worry and nervous when they do not understand the spoken text. Those who have anxiety in understanding the listening task, sometimes do the same on speaking performance. They have less confidence if they have less comprehension on English. However, sometimes they fell worry toward the facilities, like "Does the recording or the cassette run well? From the questionnaire, there are 7 students or 39\% answer 'sometimes'. It means that their anxiety happens only in some particular task, like the task that beyond their understanding. Those seven students say that they will be worry if the text is nor about their ability, like the task about law, medicine, etc. However, they will have no worries if the task is about their understanding. From the questionnaire, it is also showed that only one student answer 'never'. She felt no worries and nervous related to the material listening task or even to the material. This respondent has highest score in listening 
task. Therefore, she always prepares herself in dealing with the listening task. That nervousness is caused by some factors below:

a. Lack of confidence in dealing with the listening task

The confidence is related to their comprehension on the listening task. They sometimes raise the question like "Can I answer the question well?" Those less confidence cause their anxiety in answering listening the listening task. They say that in their senior high school, the listening tests are tested together with the other skill in one complete package. Here, listening is in small portion. They believe that even though they cannot deal with listening task, their score will be added by the reading skill or the structure and grammar mastery. However, when they sit in college, they will face those listening tasks without the other skills.

b. Characteristics of listening comprehension task

Listening comprehension consists of complex process. In listening TOEFL test, listening comprehension is tested in three section; short conversation, long conversation, and long talks. The problems arisen are not only about the vocabularies or the material, but also the time for answering the task. In listening skill task, the students are demanded to think quickly and understand the task quickly. They have limited time. They cannot go back to the previous number when they have continued the following task.

c. Worry about the negative mark from the lecturer

Sometimes, the students feel worry about their mark. It happens when the lecturer accidentally ask them to answer the question. They feel worry if their answer is incorrect. The students worry and nervousness are divided into these following factors:

1). The students' factor

a) Nature of speech

This problem related to the material of listening task. The listening task includes specific text with different level of speed, pronunciation, length, vocabularies, and context of the text. The students will feel anxiety if the material has poor pronunciation, high-speed played different accents, and unclear recording.

b) Level of material difficulty

They will get anxiety if the material is beyond their level. the students will get frustration when the tasks are too difficult, like the unfamiliar vocabularies, the complicated sentences, and unfamiliar topics.

c) Material clarity

The students will get worries if they do not know what kind of text about. It also deals with unclear instruction or the unclear guidance.

d) Visual support

Visual support is needed to get the students interest and motivation. The students get boredom when the listening tasks are in similar form, like filling the blank for some weeks or the monotonous material. Here, the lecturer needs to modify the task with some visual aids or other authentic materials.

e) Lack of repetition

Some students expressed frustration when the materials are only played once or twice. When they have only limited times to answer the test, they need extra repetition. 
2)The Process of listening comprehension

a) The listening strategies

This factor is closely related to the teacher pre-listening strategy. Some students feel doubt whether they are asked to answer the worddetailed listening task or only for answering the overall meaning.

b) Limited time for checking the answer

Some students feel anxious when they are asked to answer immediately to the listening task. Here the students need time for processing the information from the material and put it on the answer sheet. They miss the time for answering particular questions and just "choose" based on their luck when the lime is so limited.

c) Unfamiliar with listening comprehension

Some students say that they never learn listening comprehension at their extra times. They prefer to learn grammar even to practice speaking rather than learn listening comprehension material.

3) Instructional Factors

a) Less practicing

Some students only do listening practicing when they are on listening class. However, for the students of English department, listening class is only once in a week. Therefore, sometimes they feel incompetent or unprepared when dealing with the listening task.

b) The test on listening comprehension

The students are having stress or fear when they have to face the test on listening class. They prefer to do the task on weekly activities without focusing on the lecturer's mark. Here, they can ask the lecturer to repeat and give clue to the material.

c) Uncomfortable environment

The environment surrounding gives effects to the listening comprehension ability. Some students cannot focus on the listening task when the room is too hot or too cold. Sometimes, they cannot concentrate when the class is too noisy.

4) The relationship between students-lecturer

a) Fear of failure

The fear of failure gives stress for the students. It can happen because of their previous experience or the low level of risk taking.

b) Lecturer personality

The lecturer personality also gives effects on the students. The unrealistic expectation without knowing the input of learners make the students work too "hard". They will get worry if the answer is incorrect or cannot fulfill the criteria from the lecturer.

\subsubsection{They find it difficult to understand the spoken text which is not of interest to them.}

When the students are asked about the correlation between their performance and their interest related to the listening task, 15 students or $83 \%$ answer 'sometimes'. It means that the interest is not the main factor of the students' difficulties related to the listening task. The respondents say that the interest material will arouse their concentration and motivation in dealing and answering the task. However, it has no close relationship to their difficulties. When the respondents are asked about other factors related to their difficulties, some respondents say that the quality of the cassette plays the most important aspect. 
Besides, the vocabularies are also the factors. In addition, some students say that the context of the task is also the factor in dealing with their difficulties. They say that even though the task is about their interest, if the vocabularies are difficult and beyond their ability, it will be useless. Besides, the result also showed that one student answer "often" and two students answer 'never'. Those who answer never have higher listening mark on listening comprehension rather than the others.

\subsubsection{They stop listening when they have problems in understanding a listening text.}

When the students are asked about "Stop listening when they have problems in understanding a listening text", 50\% students in the class answer "sometimes". It means that they sometimes stop listening the material if they loss "understanding" dealing with the text. Besides, three students answer "often". In this case, they stop the listening task but they never put off the headphone. They just stop focusing on the material task. If the question in the form of multiple choices like on the TOEFL test listening comprehension, the keep choosing the answer without considering whether their answers are correct or wrong. However, if the task is filling the blank, sometimes they leave the space blank. Those problems are caused by many factors. The problems related to the material itself disturb their mood if the cassette or the material played too fast. Besides, sometimes it is related to the equipment. Some students say that the recordings are unclear and full of noises. It can give bad effects on their concentration. In addition, the accent of the speaker also gives effects on the students' listening comprehension. Some native-speaker says English in unusual accent. The next factor may arise from the existence of difficult words or similar-sound words. The last factor is related to the contexts that are unfamiliar for the students. If the material are beyond their imagination, they feel worry and nervous.

In addition, six students answer "never" stop listening when they get problems in understanding the text. Here, if the questions are in the form of multiple-choice question, they just choose the answer without considering it is correct or incorrect. They hope that there is "luck" for those answers. When they get the problems in understanding the task, they keep going listening the cassette. They never put off their headphone, but they just answer the choices based on their belief.

\subsubsection{If they do not arrive at a total comprehension of an oral text, they feel dissapointed.}

When the students are asked if they feel disappointed when they loss their listening comprehension, seven students or 39\% answer "often" and six students or $33 \%$ answer "sometimes" while five students or $28 \%$ answer "always". No one answer "never". In this case, they feel disappointed when they cannot answer the question. They ask the lecturer to repeat the task if they cannot finish the task well or they feel less confidence with their answer.

\subsubsection{Before doing listening comprehension tasks, they fear that they cannot understand what they will hear.}

In pre listening stage, 9 students or 50\% answer that they sometimes fear about what the material will be about. The students say that when the task are given by the lecturer, some questions are raised, like 'What the task will be about?' or 'What kind of question will be like' or "Can I answer the questions", or "Can I handle with the recording?", etc. in addition, six students answer "often". Only three students that answer they do not fear to the listening task. 
4.2. The Listening Strategies for Dealing the Listening Programs Related to the Psychological Factors

4.2.1 The Lecturer Provides the Task Based on the Students' Level and Age

To overcome the listening's problem related to students' psychological factor, the lecturer provides the task based on the students level and age. It is not only related to the context used, but also the level of vocabularies used. For listening class in Indonesian college students may be will be similar to the material for junior high school students in UK or US. Age also give effects on the topic chosen. For the seventeen until twenty years old students will get much interest if the topic tells about friendship, love, social media, online shopping, etc. knowing the students' level will make the students motivated in answering the task. Expecting too much will push the students into stress and worries.

4.2.2. The Lecturer Provides the Listening Task that Arouse the Students' Interest

Interest is subjective. Various students have different interest. It is impossible for the lecturer to fulfill individual interest. However, the lecturer generalizes the students' interest. The lecturer asks them in the end of the class to know their interest. If it is highly different, the teacher can deliver it in different week. Ages can be clues in deciding the students' interest. The teen students will be heavy interest if the task is about pop culture or modern technologies, rather than about financial loss or the founding father of scout. The students' background is also the clue for deciding the interesting task. The students in Pacitan will be difficult to comprehend the task related to Chinese cuisine that is unfamiliar for them.

4.2.3. The Lecturer Gives Extra Time in Each Section to Motivate the Students in Answering the Task.

If the listening task is divided into some sections, it is better for the lecturer to give extra time for the students in answering the task. To hurry task make the students loss their concentration. The teacher knows what the task form is. If the task is in the form of filling the blank or answering the main idea, the lecturer can play the recording more than once.

4.2.4. The Lecturer Provides Listening Task's Background Knowledge

Students' backgrounds of the students are different. Some students in Pacitan ever go to the movies; some of them have not ever seen it. Here, the lecturer can elaborate the background knowledge of the task. In the prelistening session, the students can give short explanation about what the task will be about. It can be in the form of visual or just oral explanation. Therefore, the students have time to predict about the task. It can increase the students' comprehension in listening.

4.2.5. Lecturer Should Encourage their Students to Develop Listening Strategies,

Listening strategies are very important in listening comprehension. The teacher can explain what kind of the task will be about in the prelistening section. Those strategies, such as predicting, asking for clarification, and using non-verbal cues can improve learners' listening comprehension ability.

\section{CONCLUSION}

The result shows that there are five problems related to psychological characteristic. First, the students feel nervous and worried when they do not understand the spoken text. Second, the students have difficulties in understanding 
the spoken text, which is of their interest. Third, they stop listening when they have problems in understanding a listening text. Fourth, they feel disappointed when they do not have total comprehension. Fifth, before listening, they fear that they cannot understand the text. Based on these problems, the lecturer gives some solving strategies. First, the lecturer provides the text based on the students' level and ages. This is also related to the vocabularies ability. Second, the lecturer provides listening tasks that arouse students' interest. The lecturer gives different inputs, such radio, TV, songs, lectures, advertisement. Third, the lecturer gives extra time in each section to motivate the students in answering the task. Fourth, the lecturer provides listening task's background knowledge. Besides, the lecturer gives feedback to increase students' motivation. Fifth, lecturer should encourage their students to develop listening strategies, such as predicting, asking for clarification, and using non-verbal cues to improve learners' listening comprehension ability.

\section{REFERENCES}

Atasheneh, Naser dan Izzadi, Ahmad. (2013). The Role of Teachers in Reducing/Increasing Listening Comprehension Test Anxiety: A Case of Iranian EFL Learners. www.ccsenet.org/elt English Language Teaching Vol. 5, No. 3; March 2012

Flowerdew, J. and Miller, L. (1996). Student Perceptions, Problems and Strategies in Second Language Lecture Comprehension. RELC Journal23 (2), pp.60-80.

Hamouda, A. (2013). An Investigation of Listening Comprehension Problems Encountered by Saudi Students in the EL Listening Classroom. International Journal of Academic Research in Progressive Education and Development, 2(2), 113-15.

Higgins, J.M.D. (1995). Facilitating Listening in Second Language Classrooms through the Manipulation of Temporal Variables. Unpublished doctoral thesis. University of Kent at Canterbury.

Yagang, F. (1993). Listening: Problems and solutions. In English Teaching Forum (Vol. 31, No. 2, pp. 16-19). Teacher Development, Making the Right Movies.

Yagang, F. (1994). Listening: Problems and solutions. In T. Kral (ed.) Teacher Development: Making the Right Moves. Washington, DC: English Language Programs Divisions, USIA 